Abstracta Iranica

Revue bibliographique pour le domaine irano-aryen

Volume 22 | 2001

Comptes rendus des publications de 1999

\title{
« Passants de brides achéménides de Suse », IA, 33, (1998), pp. 143-149, 4 pl.
}

\section{Rémy Boucharlat}

\section{Q OpenEdition}

1 Journals

Édition électronique

URL : http://journals.openedition.org/abstractairanica/36295

DOI : 10.4000/abstractairanica.36295

ISSN : 1961-960X

\section{Éditeur :}

CNRS (UMR 7528 Mondes iraniens et indiens), Éditions de l'IFRI

\section{Édition imprimée}

Date de publication : 15 mai 2001

ISSN : 0240-8910

\section{Référence électronique}

Rémy Boucharlat, « «Passants de brides achéménides de Suse », IA, 33, (1998), pp. 143-149, 4 pl. », Abstracta Iranica [En ligne], Volume 22 | 2001, document 110, mis en ligne le 15 février 2010, consulté le 13 octobre 2020. URL : http://journals.openedition.org/abstractairanica/36295 ; DOI : https:// doi.org/10.4000/abstractairanica.36295

Ce document a été généré automatiquement le 13 octobre 2020.

Tous droits réservés 


\title{
« Passants de brides achéménides de Suse », IA, 33, (1998), pp. 143-149, $4 \mathrm{pl}$.
}

\author{
Rémy Boucharlat
}

Une trentaine de passants de brides utilisés pour le harnachement des chevaux a été trouvée dans les fouilles de Persépolis ; les uns sont taillés dans des dents de sanglier, et sont en forme de petite corne; d'autres sont en pierre mais, par imitation, conservent la même forme. En revanche, à Suse, on rencontre non seulement cette forme de petite corne, mais aussi une autre série en forme de crochet et un exemplaire unique de forme ogivale. Tous sont en pierre. L'A. observe que sur les bas-reliefs de l'Apadana, une douzaine de peuples, dont les Perses et les Mèdes, utilisent des passants de brides, qui sont toujours représentés en forme de corne ; cela montre que si les sculpteurs avaient le goût de la précision, les représentations qu'ils créaient étaient en partie conventionnelles.

INDEX

Thèmes : 3.2.2. Pré-Achéménides et Achéménides

\section{AUTEURS}

RÉMY BOUCHARLAT

CNRS - Lyon 